ljtihad: Jurnal Wacana Hukum Islam dan Kemanusiaan

Vol. 20, No. 1 (2020), pp. 79-95, doi : 10.18326/ijtihad.v20i1.79-95

\title{
The influence of sunni Islamic values on rehabilitation as judicial decision for minor drug users in Indonesian court
}

\section{Cecep Mustafa}

Stirling University, United Kingdom

E-mail: cecepmustafa97@gmail.com

DOI : 10.18326/ijtihad.v20i1.79-95

This article illustrates how recent research uses qualitative semi- structured interviews to understand judicial perceptions when convicting minor drug offenders. To develop an understanding of what the judges were trying to achieve when convicting drug offenders, I interviewed 31 judges. This article contributes to the sociol-legal understanding of the context in which problem- solving and justice influenced by Islamic religious values work in harmony. Indonesian judges use Islamic values to support rehabilitation. This supportive approach opens the door to the influence of Sunni Islamic values as one of the legitimating values when deciding.

Artikel ini mengilustrasikan bagaimana penelitian terbaru menggunakan wawancara semi-struktur kualitatif untuk memahami persepsi peradilan ketika menghukum pelaku pelanggaran narkoba ringan. Untuk mengembangkan pemahaman tentang apa yang coba dicapai oleh para hakim ketika menjatuhkan hukuman terhadap para pelaku kejahatan narkoba, total 31 hakim diwawancarai. Artikel ini berkontribusi pada pemahaman sosiologis dari konteks di mana penyelesaian masalah dan keadilan yang dipengaruhi oleh nilai- nilai agama Islam berjalan dengan harmoni. Bahwa nilai nilai Islam dipergunakan hakim untuk mendukung putusan rehabilitasi. Pendekatan yang mendukung ini membuka pintu bagi pengaruh nilai-nilai Islam Sunni sebagai salah satu nilai yang melegitimasi saat menjatuhkan putusan.

Keywords: Sunni Islamic values; minor drug users; rehabilitation 
Ijtihad: Jurnal Wacana Hukum Islam dan Kemanusiaan, Volume 20, No. 1, Juni 2020: 79-95

\section{Introduction}

The results of the research presented in this article aim to explore the perspective of the judiciary about bringing down drug offenders in Indonesia, focusing on identifying the factors that influence drug decisions. Thus, this article examines the factors that the Judge said influenced their decisions. Hutton argues that to realize justice, one needs to know what fundamental factors contribute to the Judge's decision (Hutton, 2006: 155174). Without considering the factors that can influence the decision, it can lead away from justice. Therefore, it is necessary to acknowledge the factors considered when deciding (Ashworth, 2002: 219-236).

\section{Research methods}

To understand participant perspectives on drug decisions in Indonesia, the writer adopted a semi-structured interview research method and observation because the context investigated was relatively new. Thirty one participants were interviewed, and eighteen trials in the writer's observation received ethical approval from the Stirling University Ethics Committee. The court does not need further formal ethical approval.

\section{Previous research and theoretical framework}

In the literature review section, the writer conducted a review of previous research related to cultural factors considered when passing the verdict. Factors regarding judicial culture can be considered as factors that challenge the ruling. The judicial culture in this article is related to the knowledge that informs daily practices and shapes the values of Judges, such as bureaucratic culture. Lipsky (2010) views that as an executive-level bureaucrat, court judges at the first level are subject to the performance criteria of higher courts. Thus, judges in the court of the first instance are expected to satisfy those in higher courts (Lipsky, 2010). This is what Lipsky described as a strategy for handling the burden of cases in the judiciary. Lipsky's research illustrates how judges are influenced by the status of their bureaucracy, which requires compliance with the direction of senior judges. A supporter of the judicial countermeasure strategy claims that junior judges follow the opinions of senior judges (Klein and Mitchell, 2010). 
On the one hand, judges are "independent" (Biland and Steinmetz, 2014) and permitted exercising judicial wisdom (Thomas, 2003: 50-73). While the judges "depend" on the status of their bureaucracy which needs to give accountability to the Supreme Court regarding their performance in managing court burden. This bureaucratic culture and managerial orientation can change the judicial interpretation of justice to simply speed up the settlement of the caseload that enters the court which is considered an important criterion of a higher court (Lipsky, 2010). Because of their bureaucratic culture and under the aim of a court that promotes the efficiency of processing cases, perpetrators who wish to exercise their legal rights to be prosecuted can be more severely punished than those who plead guilty (Ulmer and Johnson, 2010: 560-592; Ulmer and Bradley, 2006: 631-670).

In the culture of bureaucracy and managerial orientation as mentioned above, they consider it necessary that judges are seen as confident when passing decisions on drug users because if they appear to be unsure of their decisions, they will question their legitimacy. I define legitimacy as the extent to which the institution seems to reflect the expectations of others in the performance (Goffman, 1959). We can consider the term legitimacy as a general term to describe the extent to which judges' interpretation of justice appears to reflect their accountability to a broader audience structure (i.e. political, public) related to drug use. In terms of political accountability, there is a direct accountability mechanism in terms of how judges interpret what justice is, in terms of one they do political work, act in the political arena, and not just judicial activities.

For example, in the jurisdiction of Great Britain, judges are appointed by the State. For this reason, judicial interpretations of justice show their direct accountability to the state (Helms, 2009: 10-20). In terms of public accountability, there is a mechanism of direct accountability to the public. For example, in the United States, judges are democratically elected by the community. Therefore, judicial interpretations of justice pay attention to the element of judicial accountability directly to the community (Ulmer and Gault, 2008: 737768). It is this presentation of judicial accountability that the writer will consider further in this article as is well known that in Indonesia, judges are appointed by the state. This article is original from Mustafa's article (2020), which explains the opportunities and challenges in imposing decisions on drug users in Indonesia. 
To explore the perspectives of judges about their role in the criminal justice system in Indonesia, the writer uses the concept of dramaturgy as the main conceptual framework to examine imposing decisions on drug offenders in Indonesia. The writer considers this dramaturgy concept to be in a broader theoretical framework related to symbolic interactions applied by the writer this paper. Erving Goffman uses role-playing illustrations to understand human interaction. According to the Goffman scheme, all humans are actors who play unique roles in various social fields. We base these roles on personal understanding and experience. Individuals use symbols during their interactions with each other. Through impression management, individuals present a pleasant image for the audience and other actors in the drama of sustainable life. Because these actions are carried out more often in teams, individuals depend on others for the supportive image they want to project relationships that are sometimes unstable (Goffman, 1959). More recently, it has adapted the concept of dramaturgy to explain the dynamics of social movements. James Nolan, for example, points out - according to Goffman's interpretative metaphor that drug court hearings, played by court actors and seen by users, are like theatre plays (Nolan, 2001).

We see the metaphor of life as a theatre as applicable to Indonesian courts at least two levels. First, this drama metaphor has a useful analytical tool to interpret how the Judge tries to influence the judicial process. The strategy of judges in decisions depends on negotiating court proceedings to avoid unfair decisions in front of the court stage, namely strategies to adjust the form of decisions that meet public expectations. Second, written scenarios and prepared performances are used to present images of judicial perceptions of the accused and encourage others about moral responsibility for decisions. Related, Indonesian courts themselves can be understood as theatre, as seen in how individual judges present pleasant images in the eyes of the audience (i.e. political figures, public and religious communities). I will examine the relationship of power that still exists in court hearings. I took the concept of dramaturgy to explain justice from the judges who took part as the judges' interaction in the court's decision.

\section{The influence of Sunni Islam on justice}

The Sunni Islamic values of rehabilitation have been introduced by Natsir in his article title: "It's not easy but it's still possible to be an abstainer here": Non-Drug Use among 
Young Men in a Slum Area in Makassar, Indonesia. The conception of "rehabilitation" could be outlined merely regarding productive lifestyles and active citizenship of young men drug users in Indonesia (Nasir et al. 2014).

Relatedly, Indonesia reflects most Muslims, which can affect several dimensions of justice in the Indonesian context (Davis and Robinson, 2006: 167-190). There are two leading schools of thought in Islam, namely Shia and Sunni Islam (see Madkur, 1974, for more information). Sunni Islam is among the dominant in Indonesia (Fox, 2004). Apart from the jurisdiction of Aceh, which applies Sharia law, most jurisdictions in Indonesia apply national law. Some district judges are neutral in religious views; one can even say it is secular (Pompe, 2005). The writer's experience as a judge illustrates that, even though there is no sharia law regarding imposing drug offenders, Islamic values do not appear to be foreign to Indonesian judges. For example, the value of moral responsibility when decide can be considered influenced by Islamic values.

There are indications identified in the Quran about three forms of justice: individual justice, social justice and moral justice. First, individual justice means that judges need to do justice for themselves and the person being judged. This individual justice requires them to be honest when deciding — following their beliefs when deciding will be considered honest and credible judges. This belief is a challenge because the conviction to imprisonment decisions and the belief not to impose imprisonment can compete with one another at the same time. In the condition that there are competing beliefs, then one way to reconcile this needs to be informed by decisions that put forward rationality. Making the best judgment of their ability when deciding will be considered in line with efforts towards justice. Second, social justice means that judges need to do justice to others and not just themselves. This social justice requires them to respect fellow judges, be fair and benefit the users and the community when deciding. Third, moral justice means that the judges are morally responsible to Allah SWT. For example, all statements of decisions in Indonesia begin with the declaration: "For the sake of justice based on the Almighty God" with accountability to Allah SWT. Also, they learn that one requirement of legitimacy in decisions is accountability to Allah SWT. Regardless of which religion they believe, the moral value of their religion can be seen to influence their approach to decisions. The influence of Sunni Islamic values when deciding on drug use are presented in the following result section. 
Ijtihad: Jurnal Wacana Hukum Islam dan Kemanusiaan, Volume 20, No. 1, Juni 2020: 79-95

\section{Results and Discussion}

In this section, the writer presents a case where non-popular politics in Indonesia can put pressure on the discretion of panel judges. The real political will to push the agenda of the war on drugs creates tension between serving the political agenda and bringing about justice. The Supreme Court's response to non-popular political influences echoes judicial concerns.

... users need shelter; they should not be released alone into the forest. They, too, are humans, not tigers! We should not do that! This has become a legal issue that we must respond to. There is no way we can imprison anyone. (Judge 30)

It is clear from the quote above that the participating Supreme Court judges considered it impossible to convict every drug offender or releasing drug offenders without support because this could trigger human rights and humanitarian issues. The following extract draws attention to the challenge of dropping the verdict of those who use drugs to jail for excess capacity:

If we catch these drug abusers repeatedly, this will cause a prison capacity full of sick people and not with people who have committed crimes. 'Committing crimes' are people who sell and distribute narcotics to commit crimes. (Judge 6)

There also seems to be confusion among law enforcement officials in the criminal justice system (including police, BNN, prosecutors and judges) about what they should respond when responding to drug use. For example, Judge 6 is concerned about the unfair actions of arresting, prosecuting and imprisoning people who are considered by Judge 6 to have committed no crime (i.e. drug users). When first asked this question about the influence of political will to push the war on drugs, Judge 9 also considered that there was no point in giving a harsh ruling under the 'war on drugs' as seen below:

What are the beneficial aspects of the legal process? There is no benefit for the State, actors, and society. So far, we still depend on the rhetoric of the "war on drugs" but what are the benefits? I am quite confused about this. Are we aware of what we have done so far? Why are drugs so important? Why drugs must be individually regulated; I do not see the benefits! (Judge 9)

The verdict which incriminates drug users under the 'war on drugs' regime is seen to harm justice, as stated by Judge 18, “... Prolonged detention has a negative effect because the perpetrators mingle with drug smugglers who are serious drug users. "(Judge 18). When first asked about the unpopular political influence on the verdict, Judge 18 considered that, 
after a drug user went to prison, his condition would be worse. In the Sample court, when considering the negative effects of imprisonment, Judge 5 illustrated that the perpetrators suffered losses from decisions under the 'war on drugs' regime. Judge 5 explained that when users who have problems with drug use spend seven months in prison, they will experience near-death experiences: "I see that for people with drug use problems, prison decisions are ineffective because, when I see the condition of a brother for six to seven months in prison, he almost died "(Judge 5). In such conditions, where the boundary between 'having to sell ' and 'using' is blurred. It is unclear whether they base the criteria on the number of drugs or the role of the offender. In this situation, the presentation of prosecution evidence is often challenging because we find it after a hearing that the users are indicted by the public prosecutor differently than they should. As a result, discriminatory practices by prosecutors add to the challenge for pursuiting justice. The writer's observations at the sample court hearing revealed that the prosecutor consulted with participants. This shows the influence of the prosecutor on the irrevocable decision in these matters.

Judge 20: Assembly: Our trial is suspended now! ...

[...] the prosecutor stood up from his chair and walked close to the table where Judge 20 (assembly) sat. The prosecutor then spoke with the presiding Judge, and the presiding Judge nodded as he listened to what the prosecutor said. The chief Judge spoke again with the prosecutor and the prosecuting attorney. He nodded and returned to his chair. Next, the head of the panel of judges looks to the right and speaks to the younger panel of members. The head of the panel of judges requested confirmation of the irrevocable decision. Then the younger assembly member nodded his head, and then the chief panel of judges looked to the left and spoke to the older member assembly when he asked for confirmation of the irrevocable decision. The member assembly also nodded his head, and then the judges looked directly at the users, showing that they had made the last decision. The trial would continue] [...]

Panel 20: Okay, the session continues [the decision in front of the courtroom stage]; we discounted the decision from five to four years, that is a minimum. How do you feel? (Extract from the Observation Record hearing, Judge 20 assemblies)

As stated above, Judge 20 (the panel) shortened the court session to allow the prosecutor to consult with the participants. The prosecutor provided his input on 
the period of imprisonment, which could be accepted within the minimum standard range of decisions. Here, the prosecutor's view of the final ruling influences the drama orchestration. Here, the Judge is told that prosecutors are more likely to appeal if the Judge's decision is below the minimum standard. Judge 20 (the panel) responded to the prosecutor's input as if he would change his mind. This finding shows that they see even the imposition of sanctions as part of negotiations.

In the study presented in this article, it proved negotiation of the judicial process in three distinct ways, namely through persuasion, encouragement and consensus. Not only court hearings on decisions influence these matters, but they also function as a negotiating factor in imposing sanctions. Interviews with District

Court judges showed that a sizable minority of participants (i.e. 4 out of 17) negotiated the judicial process in various ways. For example, Panel 6 (Urban) shows that they have a beneficial relationship with prosecutors so that before a case involving recent drug use is transferred to court, the Judge will discuss changes in the charges against the defendant with the prosecutor who sets the charges. As Judge 6 said:

So, before they brought the case to court, the prosecutor consulted me about the indictment. After that, the prosecutor changed the charges and included Regulation 127 of the Narcotics Law on drug abuse. In this way, I advise the prosecutor to change it because the Criminal Procedure Code also allows for this consultation. (Judge 6)

The above quotation highlights how Judge 6 influenced the prosecution charges before the prosecutor presented evidence in the courtroom. After Judge 6 negotiated with the prosecutor, they often changed this indictment to a lighter charge as a drug user, who only had a one-year criminal charge. The following quote illustrates this negotiated indictment: "Alhamdulillah, there has been a change, yes, Alhamdulillah, all [the prosecutors] are working to follow my direction. I feel happy and proud when the prosecutor understands my feelings" (Judge 6). This excerpt highlights the skill of District Court judges in using persuasion that results in changes in prosecution charges during the behind-the- scenes process in preparing relevant charges relating to the case.

This is the view of a few participating District Courts that perpetrators who use drugs should not be punished. This does not mean that it only takes a soft approach, but as an acceptable strategy, the court must start with a flexible approach to drug use 
and development after achieving broader public support. How this is presented might depend on the messenger. In their role as public relations officers, a few participants from participating District Courts explained that, they took advantage of media coverage to send messages to the public that they were trying to follow the rules regarding assessment and rehabilitation:

The court decision was also respected by the National Anti Narcotics Agency of the Republic of Indonesia (BNN) and by the voluntary sector on anti-anarchy against drug users (GRANAT). This case was reported, too, in Detik1 1 [online newspaper]. They all appreciate it. (Judge 4)

The comments from Judge 4 above illustrate this form of social justice. Judge 4 assume that media coverage is an excellent opportunity to send messages that reach the public, they used namely that joint regulation related assessment and rehabilitation observed in the trial as samples, Judge 28 offers a slightly novel approach on how to handle the media. Judge 28 stated that the role of the media was constructive in strategically spreading the judicial approach to the provision of care, especially when the Judge already had a friendly relationship with the media. Judge 28 believes that it is very strategic to disseminate information about the Joint Agreement of the six ministries (SKB) regarding the provision of assessment and care. Judge 28's comments are very precise:

After coming down from the minimum ruling, the prosecutor questioned. Then we offer them an explanation; we use the Joint Decree as the basis for our decision. I offer them a copy of the Joint Decree and, also, keep on informing them. I share this Joint Decree through the media and also; I keep telling the media that, once a member of the community using drugs, it would be better for them to be referred to rehabilitation. (Judge 28) The above quote highlights the strategic relationship of Judge 28 in disseminating drug user referrals to rehabilitation. Relations with the media, according to Judge 28, must be developed from time to time. For Judge 28, this is a deliberate strategy to bring social justice to the public. For Judge 28, they process strategic relations through coordination between institutions and information sharing. Judge 28 believes this is a relationship inter-agency communication must proactively develop that, and Judge 28 will work with the media to build cooperation and share information. It is this interagency collaboration that channels 
"more informed public opinion" and more reasonable and realistic public expectations for rehabilitating drug users:

I can tell the head of the local BNN in the regional jurisdiction, about the Joint Decree and about providing rehabilitation. After several attempts by the media to help inform the public about the Joint Decree. The rehabilitation process begins before they bring the case to court. We advise their families, also, at the trial, that the purpose of this ruling is more an approach to care. (Judge 28)

Here, Judge 28 highlights a minor part of the relationship of participating sample court judges with regional BNN agencies, the media and the public in seeking broader support for user rehabilitation. A few participants who took part showed an effort to gain media support in informing the local BNN and we brought the community about an agreement to provide rehabilitation to court.

This study shows that a small proportion of participating in City Courts are tolerant of the purpose of imprisonment. Interview data show that decreasing decisions is a way to reduce prison overcrowding. During my observations, a small portion of the taking part Court members sought to present a relative awareness of the distribution of justice from an individual perspective:

Lawyer: we consider the judges to be God's second hand in the world. This objection is for the sake of justice. I believe that the Judge will take our objections seriously.

Judge 12 of the panel: To the perpetrators, pray that our process will go well. Also, we can realise justice, not too hard or not too soft because justice is relative, you might feel it is fair, but not for the opponents 2 [prosecutors]. (Extract from the Observation Record hearing, Judge 12 assemblies)

The above quote from a court hearing observation is an example of how Judge 12 (the panel) found the basis for 'wisdom' based on their understanding that they are 'God's second hand'. The moral responsibility of the panel of judges when deciding is marked by high expectations within the community. They negotiated this expectation through drama orchestration on the courtroom stage. Religious perspectives inform and give meaning to the functions of court drama. 


\section{Discussion}

This section aims to discuss the legitimacy of the judiciary and its contribution to science. Several participants in this article present various approaches to seeking legitimacy. I define legitimacy in this article as the extent to which an agent seems to reflect other expectations in the endorsed performance. This perspective on legitimacy will help explain the idea that the performance that is validated depends (Goffman, 1959) on audience recognition. Data analysis from trial observations and interviews show that judicial considerations of their role centre on legitimizing their performance in their hearings. It is essential for some participants that this hearing recognizes their performance to balance the tension between realizing justice and public service. Several judges considered that they needed to adjust their performance to fit the view of the audience during their interaction. In line with Goffman's view of self-presentation, some participating judges considered the audience's view to be influential. Self-presentation was proven in how many participating judges reported adjusting their approach to the expectations of various hearings in the sample court. I have reflected the interaction of the judiciary with their hearings in imposing sanctions. This approach two sanctions reflects the dynamics of several panel judges in a group to form interactions with their audience. I contextualise such judicial interactions in their political, public and religious status in their actions regarding issues around justice, which will be explained in the following paragraphs.

First, regarding political status, a real political desire to advance the agenda of the war against drugs creates tension between serving the political agenda versus realising justice. Efforts to bring about justice often conflict with political considerations aimed at maintaining power. Most participating judges do not yet have the confidence to reconcile this tension. They reflect this in their duties by only doing what the State wants. The writer has taken this from the finding that in court hearings, most participating judges suspended the court hearing to allow prosecutors to consult with the participants. Prosecutors, as representatives of the State provided their input on the acceptable period of imprisonment within the minimum standard range of decisions, bearing in mind that prosecutors would likely appeal if the participants' decisions were below the minimum standard. Most participants received input from prosecutors about the length of the prison sentence. 
Thus, imposing sanctions is negotiated and is not pure compassion. While in other ways, a few participating judges seemed to develop their confidence. They reflect the development of this belief in the exercise of judicial policy. The participating judges persuade other panel judges to heed their moral compassion and responsibility and do not consider how a minimum standard decision will apply to that person; this encourages judges to adjudicate other decisions below the minimum standard. Their compassion and moral responsibility encourage them to adapt their interpretations of justice to circumstances. This provides accountability for political pressure, and the judges seem to put forward their policies. Therefore, the judicial policy is considered healthy here for democracy; Judges have a role in interpreting or trying to achieve a balance in law with their interpretation of achieving broader social justice. In other contexts, some legal scholars consider the judiciary to be the Judge sitting in court during the judicial process, the law reflects democracy, and the panel of judges is only as an executor of the law, without having to have extrajudicial discretion (Hart and Green, 2012). The judicial interpretation can be considered as a reflection of their political accountability. For example, in US jurisdiction, judges are democratically elected by the community, so that judicial interpretations of justice reflect their direct accountability to the community (Ulmer and Gault, 2008: 737-768). In UK jurisdiction, judges are appointed by the State, so that judicial interpretations of justice reflect their direct accountability to the State (Helms, 2009: 10-20). Some critics say that a judge is democratically elected, and that there is a direct accountability mechanism in how they interpret what justice is, in the sense that they do political work, act in the political arena, and not just carry out activities in court. This political accountability can reflect what the Judge does.

In this article, several participants admitted finding the influence of political pressure on drug decisions. We see political pressure as a challenging factor that limits their capacity to exercise wisdom, given that participants are appointed by the state, so decisions made by some participating judges cannot be fully politically independent. Therefore, the aim of delivering the verdict to the accused drug users is to provide direct accountability to the state. The participants also have bureaucratic status; they must obey their superiors: supervising inspectorates from higher courts. Instead of encouraging participants to do good discretion, the inspectorate felt pressured on several participating judges to stand firm and maintain the 
law enforcement process. The current system of accountability seems to put pressure on participants to follow the minimum criminal decisions. This system of accountability creates unhealthy conditions - specifically where accountability is measured by legal compliance with minimum criminal rulings. This system of accountability makes most of the participating judges present a solidarity to heed their moral responsibilities and use useful wisdom. After exercising discretion, they hope that the Court of Appeal will consider the basis of their decisions based on morals and accept limitations in the rendering of their decisions and adjust (Mustafa, 2020; Mustafa et al. 2020). The formation of this solidarity to implement meaningful policies can be considered as the dynamics of judges responsive to political and bureaucratic pressures in their actions on issues surrounding justice.

Second, in the public's case, the presentation of justice depends on public acceptance. Concern over sceptical public opinion about allegations of corruption is likely to make most judges who participate in situations of indecision when responding to public demands for accountability. In contrast, the majority of participating judges avoided decisions that would attract public accusations. This avoidance can limit their chances of gaining public acceptance. However, a small proportion of participating judges seem to develop interactions with the public due to public expectations in terms of rehabilitation support available to drug users. This public expectation seems to make a few participating judges to consider the beneficial aspects of their decisions to users and the level of public acceptance. To consider the level of public acceptance, a small portion of the participating judges interact with the public to gain public legitimacy. According to Goffman, getting legitimacy requires conditions that allow group members to reflect the expectations of others in the performance. This point of view will help explain that the notion of validated performance depends on the participant's presentation of a balance between reflecting public expectations and realizing justice. They tried to negotiate their role as a support to drug users and accountable to the public.

In negotiating their accountability to the public, a small portion of the participating judges seemed to reflect public expectations regarding rehabilitation support for drug users. The way they view their supportive role is contextualized in Sunni Islamic societies regarding what they consider an acceptable judicial response. In the supportive role expected of these 
Ijtihad: Jurnal Wacana Hukum Islam dan Kemanusiaan, Volume 20, No. 1, Juni 2020: 79-95

judges, a few participating judges appeared to respond to these public expectations. For example, a small proportion of participating judges have a dual role as public relations officers. As public relations officers, they inform the public through the media. In seeking validation, before approaching the terms of care, they shared common rules related to assessment and rehabilitation (SKB) with the media. They test how the audience provides feedback, to gain insight into the level of public acceptance. They seek feedback from the public to check whether their response is acceptable. They use dramaturgy competence by displaying two-way communication processes.

Third, in the perspective of religion, we can consider decisions as part of serving Allah SWT. Therefore, part of the responsibility of the court is for Allah SWT. This accountability to Allah is contextualized in the Sunni Islamic community. This view will include the way the panel of judges view the lawyers of the perpetrators as God's second hand in the world and the verdict as a call to ijithad. The Sunni Islamic values can be considered as a potential source of legitimacy that takes place in communicative relations, where participants consider realizing justice as part of giving up their responsibility to Allah SWT. The viewpoint of the value of religion as one of the legitimating values will help explain the influence of Sunni Islam as a legitimate value that forms judicial interpretations of justice. In considering whether the influence of Sunni Islam will lead to the basic conditions of legitimacy will partly depend on the presentation of justice when passing the verdict.

From a fresh perspective, the findings show that a small proportion of the participating judges are trying to adopt a supportive approach. This supportive approach refers to perspectives derived from socio-economic explanations for drug use that are united by judicial preferences to maintain the impression of having considered mitigating matters in the decision. They base the impression of relief in this decision on religious and supportive principles, not the principle of punishment (Mustafa, 2018: 93-110). The principle of support based on religion is an important difference that will distinguish the uniqueness of the case study court given its cultural context. Considering a supportive approach to drug users who suffer from socio-economic problems has been considered by participating judges when passing verdicts. This supportive approach opens the door to the influence of Sunni Islamic values as one of the legitimating values when deciding. Sunni Islamic values seem to be more 
suited to the internalization of moral responsibility than the orientation of decisions. Viewed from this perspective, religion influences forms of justice. The first form of justice is legal justice (Duff, 2001; Duff and Garland, 1994); the second is moral justice; the third is social justice. The term social justice used here refers to the beneficial aspects of decisions both for the user and the community. In this article, a small proportion of participating judges strive to achieve social justice. Imposing a short verdict on drug users should enable users to receive early exemptions and to allow treatment of users outside of prison. a few participating judges felt that imposing this short decision was in line with justice. They base efforts to achieve social justice on the values of moral responsibility. Also based on the concept of 'victims of the situation', and by understanding behaviour in a sociological context. The reappearance of moral responsibility values, together with ongoing support from the Sunni Islamic community, will lead to the basic conditions of legitimacy.

Regarding the limitations of the research method, the writer's position as an independent researcher but with Court connections allows for potential bias. The previous background of the writer as a judge and the current status of the writer as a researcher can influence the responses of participating judges. For this reason, the writer try to be careful not to make assumptions about this research topic as far as possible. I provide excerpts from interviews, which are not only visible to the reader, but which allow, also, interpretations of the data to be assessed. However, the writers' efforts to increase trust in research findings are not without limitations because of the influence of the writer in each stage of data analysis.

\section{Conclusion}

In this article, the writer presents the case that most participating judges will work with the media to share information that serves as an important mechanism in negotiating the form of decisions that meet the expectations of the community. The current context in Indonesia, which reflects the Sunni Islamic community, this religion influence several dimensions of justice (Davis and Robinson, 2006: 167- 190). The Sunni Muslim community is supportive of decisions for rehabilitation. This support serves as an important aim in negotiating the form of decisions that will achieve broader social justice. This confirms symbolic interactionism and Goffman's concept of dramaturgy. And this makes this 
ljtihad: Jurnal Wacana Hukum Islam dan Kemanusiaan, Volume 20, No. 1, Juni 2020: 79-95

research significant and very original in judicial decisions and the influence of Sunni Islamic values as one of the legitimating values when deciding.

\section{Bibliography}

Ashworth, A. European sentencing traditions: accepting divergence or aiming for convergence? In: C. Tata and N. Hutton eds. Sentencing and society: international perspectives. Farnham: Ashgate Publishing, 2002: pp. 219- 236.

Biland, É and Steinmetz, H. The judiciary and the boundaries of street-level bureaucracy: family judges in France and Canada. Glasgow. ECPR General Conference, 2014.

Davis, N. J., \& Robinson, R. V. The egalitarian face of Islamic orthodoxy: support for Islamic law and economic justice in seven Muslim-majority nations. American Sociological Review, Vol. 71 No. 2, 2006 pp.167-190.

Duff, R.A. Punishment, communication, and community. Oxford: Oxford University Press, 2001.

Duff, R.A. and Garland, D. A reader on punishment. Oxford: Oxford University Press, 1994.

Duff, R.A. and Garland, D. Sociological perspectives on punishment. Oxford: Oxford University Press, 1994.

Fox, J. Currents in contemporary Islam in Indonesia. Canberra: Australian National University, 2004.

Goffman, E. The presentation of self in everyday life. Garden City, NY: Anchor, 1959.

Hart, H.L.A. and Green, L. The concept of law. Oxford: Oxford University Press, 2012.

Helms, R., Modelling the politics of punishment: a conceptual and empirical analysis of 'law in action' in criminal sentencing. Journal of Criminal Justice, Vol. 37 No. 1, 2009: pp.10-20.

Hutton, N. Sentencing as a social practice. In: S. Armstrong and L. McAra eds. Perspectives on punishment: the contours of control. Oxford: Oxford University Press, 2006: pp.155-174.

Lipsky, M. Street-level bureaucracy: dilemmas of the individual in public service. 30th Anniversary ed. New York: Russell Sage Foundation, 2010.

Klein, D.E. and Mitchell, G. The psychology of judicial decision making. Oxford: Oxford University Press, 2010.

Kramer, J.H. and Ulmer, J.T. Sentencing guidelines: lessons from Pennsylvania. Boulder., Lynne Reiner Publishers, 2009. 
Mustafa, C. "Punishment, in fact, did not resolve the problem": The judicial perspectives on the sentencing of minor drug offenders in Indonesia. In Papers from the British Criminology Conference, Vol. 16, 2018: pp. 93-110.

Mustafa, C. The perceptions of Indonesian judges in sentencing minor drug offenders: challenges and opportunities. Jurnal Hukum dan Peradilan [Journal of Law and Court Justice], Vol.9 No.1, 2020: pp 1-26.

Mustafa, C. Malloch, M. Smith, NH. Judicial Perspectives on the Sentencing of Minor Drug Offenders in Indonesia: Discretionary practice and compassionate approaches. Crime, Law and Social Change. Vol.9, 2020.

Madkur, M. S. Manahijal-Ijtihad fi al-Islam [The Methodology of Legal Reasoning in Islam], alMatba'ah al-'Ashriyah al-Kuwait, 1974.

Nasir, S., Rosenthal, D., \& Moore, T. (2014). "It's not easy but it's still possible to be an abstainer here": Non-Drug Use among Young Men in a Slum Area in Makassar, Indonesia. International Journal of Criminology and Sociology, Vol. 3, 2014: p.336.

Pompe, S. The Indonesian Supreme Court: a study of institutional collapse. Ithaca, NY: Cornell University Press, 2005.

Nolan, J.L. Reinventing justice: the American drug court movement. Princeton, NJ: Princeton University Press, 2001.

Thomas, D. Judicial discretion in sentencing. In: L. Gelsthorpe and N. Padfield eds. Exercising discretion: decision making in the criminal justice system and beyond. London: Willan, 2003: pp.50-73.

Ulmer, J.T. Eisenstein, J. and Johnson, B.D. Trial penalties in federal sentencing: extra $\square$ guidelines factors and district variation. Justice Quarterly, Vol. 27 No.4, 2010: pp.560592.

Ulmer, J.T. and Bradley, M.S. Variation in trial penalties among serious violent offenses. Criminology, Vol. 44 No. 3, 2006: pp.631-670.

Ulmer, J.T. Bader, C. and Gault, M. Do moral communities play a role in criminal sentencing? evidence from Pennsylvania. The Sociological Quarterly, Vol. 49 No. 4, 2008: pp.737-768. 
